\title{
Lesson Observation Practice of Mathematics Teachers through School University Partnership Mediated by Lesson Study
}

\author{
Fitriati Fitriati ${ }^{1}$, Roslinda Rosli ${ }^{2}$, Zanaton H. Iksan ${ }^{2}$ \\ ${ }^{1}$ Doctoral Program in Mathematics Education, Faculty of Education, Univesiti Kebangsaan Malaysia, Bangi, Malaysia \\ ${ }^{2}$ Faculty of Education, Univesiti Kebangsaan Malaysia, Bangi, Malaysia \\ Email: zanaton.iksan@ukm.edu.my
}

How to cite this paper: Fitriati, F., Rosli, R., \& Iksan, Z. H. (2022). Lesson Observation Practice of Mathematics Teachers through School University Partnership Mediated by Lesson Study. Creative Education, 13, 675690. https://doi.org/10.4236/ce.2022.132042

Received: January 28, 2022

Accepted: February 20, 2022

Published: February 23, 2022

Copyright $\odot 2022$ by author(s) and Scientific Research Publishing Inc. This work is licensed under the Creative Commons Attribution International License (CC BY 4.0).

http://creativecommons.org/licenses/by/4.0/

\begin{abstract}
Background: Observation is a critical component of lesson study implementation. To perform high-quality lesson study, teacher must possess the ability to observe lessons in order to gather data, information or evidences of students' learning. These data are beneficial for developing high-quality reflections that will help shape their future education. This practice develops into powerful components of the teacher professional development program. Objective of the Study: To examine pre-service and in-service mathematics teachers' observation practice while participating in school university partnership mediated by lesson study (SUPER-LS) program. Methods: The case study technique was employed in this study, which included eleven prospective mathematics teachers from a university and four mathematics teachers from a secondary junior high school who were purposely selected to participate. They were recruited to the SUPER-LS program, trained in lesson study, and conducted lesson study cycles. Between August and December 2021, data were collected using a variety of instruments, including observation report, pre and post survey, which were then analyzed qualitatively. Results: It was found that teachers' observation practice focused mostly on students learning involving students learning, students' behavior and student's disposition. However, there is still a few of pre-service teachers focusing on teacher performance and most the observation focus was stated generally without enough evidences and rigorous explanation. This study suggested that teachers require additional exposure to observe lesson in order to gain a thorough knowledge of their students' learning and to provide meaningful feedback during reflection sessions which is salient in maintaining high quality lesson study.
\end{abstract}

\section{Keywords}

Observation Practices, School University Partnership, Lesson Study, Mathematics 
Education

\section{Introduction}

Lesson study (LS) is seen as a vehicle for professional development and research adapted from Japan that enables small groups of teachers to plan, observe, analyze, and refine actual classroom lessons. The main elements of lesson study consist of collaborative design of the lesson (plan), execution of the design with observation (do), and reflection on the product with a view to its improvement (see). The distinctive components of lesson study compared to other professional developments models is open class where teacher opens their lesson to be observed by other teachers (Saito et al., 2007). Observation activity focusing on pupil learning and other related evidence is the key point of the lesson study (Lewis \& Hurd, 2011; Wood et al., 2020). Through this activity, teacher can continuously learn from best practices of their colleges and that this learning can reflect in their own lessons. To achieve this, teachers need proper observation skills. In addition, as LS put a collaborative lens on student learning especially their thinking, effective observation is powerful tool for capturing evidence of learning (Lewis \& Hurd, 2011; Myers, 2012; Lomibao, 2016). It was highlighted the need for careful observation of students learning and suggested that it is important to watch their faces and eyes whilst they are involved in learning activities. In the light of this evidence, it is clear that if observation is going to be a worthwhile experience, as it is crucial to prepare teachers to recognize and identify key teacher and student behaviors in the learning environment. Observing and analyzing others' lesson helped teacher gain a better understanding of students' way of thinking and learning mathematics concept, as well as a broader understanding of mathematics teaching ideas and pedagogy (Lomibao, 2016). As the result, it is imperative to provide teachers with essential training.

Unfortunately, while it is assumed that observation plays a critical role in enhancing future teaching performance, several studies have discovered that observing student learning within LS enterprise is challenging and complex (Lewis, \& Hurd, 2011; Yoshida, 2012). Larssen et al. (2018) point out that the process of observing a lesson is frequently poorly explained, making it difficult to determine how an observation was conducted and how data were collected. Additionally, the study noted that this could be due to a lack of a frame of reference for how to improve the effectiveness of observation activities as proposed in early studies. It was discovered that the observation focus varied, with some of focusing on the teacher, some on students and their leaning, some not indicated at all. Moreover, studies found that unskilled and novice teachers often lack established observation skills, and focus on fewer specific instructional action when observing a lesson (Myers, 2012). In addition, worldwide lesson study practice does not often involve live observation lessons (Wolthuis et al., 2020), demon- 
strating the inadequacies of observation as a tool for observing learning is prevalent (Wood et al., 2020). Even, when it is used, the majority of observers of lesson study cycle place a greater emphasis on administrative aspect of lesson, with less focus on student learning and their thinking process as expecting in lesson study (Lewis, 2016; Saito, 2012; Bozkurt \& Yetkin-Özdemir, 2018). Failing to focus on student learning during the observation, might put LS in risk by being seen as a poor This demonstrates that teachers need to develop a skill to undertake observation focusing on student learning in order to ensure that the goal of LS was met.

Furthermore, an inability to articulate and conduct observation in appropriate way may result in superficial reflection, resulting in a failure to improve lesson (Lewis \& Hurd, 2011; Baldry \& Foster, 2019; Larssen et al., 2018). This is because reflection is critical to conduct effective LS and so increasing the quality of instruction (Suratno \& Iskandar, 2010; Ono et al., 2013; Iksan, 2017). Data about student learning, strength and weaknesses of the lesson collecting from observation session will be used as evident to support reflection (Vermunt, et al., 2019). Observation and data collection became more purposeful and the post lesson discussion grew more focused and in-depth (Yoshida, 2012; Yoshida \& Jackson, 2011). In other word, observation skill is inextricably tied to reflection session which is pivotal part of lesson study.

For these reasons, experiences that enable pre-service and in-service teachers to observe teaching are viewed as critical component of teachers' education and professional development, and there is even a growing movement to incorporate observation on in higher education with the goal of enhancing the quality of university teaching and learning (Myers, 2012). While our understanding of observation continues to evolve and change, teacher must practice lesson study in order to develop the observation capability and habits of mind while also being aware of the tensions associated with their use. This study conducts school university partnership mediated by lesson study (SUPER-LS).

In this study, SUPER-LS program was used as an approach to promote observation among secondary school mathematics teachers because it embodies the professional development trait of enhancing teacher capacity. This program was launched by Ministry of Education, Culture, Research and Technology of the Republic of Indonesia in 2021 as part of implementation of "Merdeka Belajar Regulation". This program aims to link and match the teacher education institutions as future teachers' producer with schools as teachers' user by capitalizing the power of lesson study. While, there is a substantial body of research devoted to improve teacher knowledge through engaging lesson study (Fauziah et al., 2022; Asari et al., 2018; Thinwiangthong et al., 2020) and reflection skill (Ono et al., 2013; Iksan, 2017; Fen et al., 2017; Bozkurt \& Yetkin-Özdemir, 2018; Hummes et al., 2019), studies devoted to observation practice are sparse. Therefore, additional research is required on the foci on observation practice among mathematics teachers. The contribution of this study is obvious, as the study's findings can be capitalized as guidelines for develop and conduct teacher training. Thus, 
the purpose of this study is to examine pre-service and in-service mathematics teachers' observation practice during their participation in SUPER-LS program.

\subsection{Literature Review}

\subsubsection{Observation Practice}

Observation is a technique that is used in educational research. It possesses tremendous potential to advance our understanding of teaching and learning by capturing the process of instruction through the lens of teaching behavior and the students' response, which can be used to improve instruction. It is regarded as constructive criticism in order to advance and value teachers continue improvement, personal and professional growth (Vermunt et al., 2019). As a result, it has been widely adopted as a component of teacher professional development program. In lesson study, one of a model of professional development programs, observation is viewed as a critical activity for successful of lesson study implementation (Lewis, 2011; Myers \& West, 2012; Saito, 2012; Lomibao, 2016). In lesson study cycles, observation is the process takes place between peers, ideally in an atmosphere of mutual support and collaborative inquiry, with the goal of resolving pedagogical challenges (Wood et al., 2020). The designed lesson is experimented in the classroom by volunteer teachers while their colleagues observe and collect the data for reflection in the post lesson session. Numerous studies in the literature have documented the value of the lesson observation including: as a method for examining classroom practices and gaining insight into how student learn (Wood et al., 2020; Wolthuis et al., 2020); and as a powerful tool for capturing evidence of learning for evaluative reflection (Lewis, 2011; Myers \& West, 2012; Saito, 2012; Lomibao, 2016; Wolthuis et al., 2020). These have been extensively used in many adaptations of lesson study.

When observation is accepted as a critical activity in the lesson study, it is necessary to consider how it should be conducted effectively and what should be observer in order to accomplish its objective. Saito (2012) found that the method of observation used in a series of works is not as well described as guideline or guide books. The descriptions are likely to remain general in nature, such as where to stand while observing a lesson or the importance of conducting as many observations as possible. This also appeared in Olson, White and Sparrow (2011) study who suggested that teachers moved around the classroom during the research lesson to observe what students were doing at their desks and asked the students questions to ascertain why they used a particular approach to solve problem. Dudley (2014) suggests that each observer should make a concentrate effort to observe two or three students (a group of students), but do this in details. He also suggested that during the planning meeting, the chosen students for observation should be identified and a note made of their learning reaction. Meyer and Wilkerson (2011) added that observers were not permitted to interfere with the research lesson by conversing with students and were required to record as much as details as possible about their observation focus. In addition, Fernandez et al. (2003) explained that the Japanese teachers observed the lesson 
to collect the data by writing detailed and copious notes about how the lesson unfolded directly on their lesson plan. Lewis and Hurd (2011) outline a five procedure for observing a research lesson: 1) respect the classroom atmosphere (silent phone, avoid side conversations, and arrive on time and stay for the entire classroom, 2) avoid assisting student or interfering with natural flow of the lesson, 3) collect data requested by lesson planning team; 4) focusing on a single student (or group of students) over the entire classroom is likely to yield insight whether and how the students developed understanding; 5) ask clarifying questions of a student after lesson is terminated. Expert said that the observation skill will develop as a result of continuing lesson study practice.

In term of observation focus, there have been several studies in the literature reporting on what to observe during a lesson. Lewis (2016) and Saito (2012) described that observation in lesson study is focused upon students rather than teachers and provide information to lesson study practitioners. Vermunt (2019) explained that observation focus on students learning and their process of learning, the difficulties they encounter, the understandings they develop, and misconceptions that emerge as they articulate what they are learning. According to Larssen et al. (2018), observers can observe student reaction, facial expressions and interactions with others Murata (2011) and Wolthuis et al. (2020) proposed that teachers pay attention to student thinking and take notes on student and teacher dialogues as well as observation notes on manipulative use and student work. Fernandez et al. (2003) noticed an interesting point of observation in the lesson study originally conducted in Japan: students' motivation and participation in the lesson. They mentioned that teachers In Japan has a long tradition of focusing on student and their learning. According to some expert teachers, a watershed moment in their professional development occurred when they observe a lack of sensibility in students and their learning. In Japan, calming down students and enticing them to participate in learning has been a major challenge and a result, lesson study has been employed with considerable difficulty. Thus, teacher must make an attempt to view students and their learning holistically. These demonstrate that the observation characteristics include a focus student growth and an attempt to gain a deeper understanding of the meaning and process of learning for each student. These circumstances would include non-verbal communication and classroom environment and atmosphere as well as the cognitive and affective aspect of students' learning

There are three approaches to observation as mentioned by Wood et al. (2020) which is also referred to as a simple typology of observation approaches:

- Unstructured approaches: the observer operates outside of a formal framework and records thoughts, reflection and observation in unstructured manner.

- Semi-structured approaches: the observer is provided with a set of pre-defines categories that help shape the observation focus and the areas of interest and may include the use of assessment criteria to evaluate and possible grade teacher quality.

- Structured approaches: the observer makes use pre-established categories but 
may also need to make use performance indicators to assess specific aspects of the observation.

Based on this typology, the community learning members of the SUPER-LS used semi-structure approach to observe the lesson. Given the critical nature of lesson observation in term of teaching improvement, both pre-service and in-service teachers should have adequate experience with lesson observation, and one approach to do so is through a school-based TPD called school university partnership mediated by lesson study.

\subsubsection{School University Partnership Mediated by Lesson Study}

School-university partnerships is critical feature in a variety of international contexts for improving three education including initial teacher education, induction, continues professional development and even to research development in teacher education (Green et al., 2020; Khin \& Sin, 2021). It plays a critical role in the development of innovative teaching and learning communities that draw on the expertise of university academic and school teachers to bridge the theory and practice, as well as those engaged in academic research (OECD, 2016; Farrell, 2021). Many research studies have established the benefits of establishing school-university partnership in preparing mathematics teacher education, demonstrating significant gains in professional knowledge, research development and knowledge creation (Tsui et al., 2009; Green et al., 2020; Khin \& Sin, 2021; Farrell, 2021). Therefore, to foster knowledge creation and dissemination in mathematics teacher learning, one recommendation is to place a premium on partnership between schools and universities in order to improve the quality of mathematics education.

However, partnerships are frequently reported as difficult and challenging (Larssen et al., 2018; Baldry \& Foster, 2019), as schools and universities are rarely completely aligned. Universities may emphasize the value of critical perspectives on teacher education by emphasizing theory and the weighting of academic evidence. Schools may be concerned with implementing practical method of instruction in order to accomplish more immediate goals (Marsh, 2021). The difficulties inherent in establishing school-university partnerships have been documented in several research body including time consuming, asymmetrical relationship and different interest (Saito et al., 2007; Marsh, 2021). For these issues Japanese lesson study is seen as a solution to bridge the gap between these entities (Saito et al., 2007; Tsui et al., 2009; Hendriana et al., 2016; Hendriana \& Supriatna, 2016; Baldry \& Foster, 2019). With its demonstrated potentials for improving teaching and teacher quality, lesson study inevitably raised the issue of school-university partnership to support the process of teacher education. Thus, many countries around the world offered school-university partnerships mediated by lesson study as an approach of teacher professional developments. This partnership allows pre service teachers to participate in lesson study cycles conducted by in service teachers to do so within an extremely well-established framework.

To maximize this learning opportunity, three critical components are re- 
quired: 1) a well-researched lesson plan with a compelling reason; 2) live observation of the lesson with a diverse group of participants; and 3) a focused postlesson discussion based on participants' observations. These components are at the heart of lesson study and are pivotal for teachers to reflect on their own practice and acquire lifetime learning skills for enhancing classroom instruction (Yoshida \& Jackson, 2011).

\section{Methodology and Design}

\subsection{Study Design}

This qualitative study employed case study design. This design was chosen because it focuses on discovery, interpretation and insight rather than hypothesis testing. It is distinguished by the case or study delimitation. The object of the study could be a single person, a specific group of individuals, a program, a policy, or a specific location, as long as it represents some sort of phenomenon to be studied (Merriam, 2009). Because of this reason, a case study was used to explore teachers' observation practice during their participation in SUPER-LS. A The case involved two group of secondary mathematics teachers, pre-service teachers and in-service teachers, who engage in a cycle of four lesson studies over the course of six months. The objective was to uncover a new and deeper understanding through the use of multiple sources of evidence (Yin, 2009). Each teacher observation practice was examined in order to ascertain how teachers described their observations during and after the lesson study cycle.

\subsection{Sample Size, Sampling Technique and Data Collection}

Eleven pre service teachers and four in-service teachers were participated in this study. The pre-service teachers were enrolled in the researcher' Secondary School Mathematics Instruction Course during their third year of study at a private university's mathematics education department. They were comprised of two males and nine females. While in-service teachers included one male and three females secondary school mathematics teacher from a junior high school in Banda Aceh, Indonesia. The four in-service teachers were all government employees with a minimum of ten years of teaching experience. They have never participated in a lesson study.

The participants were selected through purposive sampling as it was important that they were trained with lesson study. All student teacher enrolled to the course automatically become the participants, while in-service teachers were recruited through their school principal to participate in the program. Both group of participants were trained with lesson study prior to conducting their lesson using the SUPER-LS program.

For data collection, this study employed two data collection techniques including observation report written by participants and pre and post survey. Participants were requested to fill the survey at the beginning of the LS program and at the end of the program. The questions ask in this survey related to SUPER-LS, 
however, this study utilized observation related questions only. In addition, participants were asked to write observation report after the lesson to collect data related to their observation practice.

\subsection{Research Setting}

To examine change of observation practices, this study conducted SUPER-LS program as school based TPD model. This project was initiated and funded by Indonesian Ministry of Education in 2021 involving 65 partnerships between university and school in Indonesia with more than 300 school teachers from the different subject area involved. Our partnership is one of them. Community learning was established as a means of implementing lesson study through this program. The program began in August and terminated in December 2021 and it was held at a junior high school where in-service teachers worked and at the university where pre-service teachers studied. The program was divided in two sessions: First session involved conducting lesson study with in-service teachers in the school by engaging pre-service teacher from university to observe the process; and the second session involved conducting lesson study in the university with lecturers in mathematics education department and pre-service teachers. In the first phase, two research lessons were proposed based on students' problem to be solved together. The following Table 1 summarizes the research lesson developed and practiced in partnership program.

The community's members, who included university tutors and in-service teachers collaborate to plan, conduct and reflect on the lessons Each teacher should put the lesson plan into practice by opening their class to be observed by other teachers. Regarding the observation process through four open classes, the teachers was assigned to observe a group of students only during the lesson implementation as suggested by Dudley (2014), by focusing on the goal of the research lesson proposed. They were required to write an observation report of the observed group in order to collect evidence of learning for use in the post lesson discussion.

On the basis of this experience and best practices, the university tutors applied lesson study in the targeted course with their colleagues. Regarding the observation training, the participants were given an observation guideline using semi-structure

Table 1. Research lesson proposed by in-service teachers.

\begin{tabular}{cccc}
\hline Teacher & Research Lesson & $\begin{array}{c}\text { Grade/Number of } \\
\text { Student Involved }\end{array}$ & $\begin{array}{c}\text { Cycle/ } \\
\text { Schedule }\end{array}$ \\
\hline \multirow{2}{*}{ ZM } & $\begin{array}{c}\text { Employing Discovery Learning Model To } \\
\text { Enhance Students Critical Thinking Skill }\end{array}$ & VII/14 & $\begin{array}{c}2 \text { cycles in } \\
\text { October 2021 }\end{array}$ \\
& Enhancing Students' mathematical & & 2 cycles in \\
HS & Disposition, Communication and & IX/15 & November \\
& Collaboration skills Using Cooperative & & 2021 \\
\hline
\end{tabular}

approach where the participants used pre-established categories, but also need to 
make use of performance indicators for particular aspects of the observation.

\subsection{Data Analysis}

All data collected including observation report, pre and post survey, were analyzed qualitatively. The analysis of observational data of the excellent teacher observation practices involved four stages. The first stage is managing data where the researcher making a folder for different data sources including participant responses for pre and post survey, and observation report. The second stage is the data analysis process in which reading and coding of the report according to the themes and sub-themes, this was conducted using NVivo software. The final stage was process of making the formulation and justification of the data that had been analyzed and the writing of the reports for findings of this study. To provide validity to the findings, triangulation of data was uses through the collection and analysis of two different data sources and included observation report, pre and post survey. The coding was compared across the fourth lesson study cycles to explore any changes in the teachers' observation.

\section{Results}

The result of the analysis of observation report and transcript of video recordings are dived into three main sections: 1) pre and post survey results 2) pre-service mathematics teacher practice and 3) The data shown that group of mathematics teachers have improved their observation skills. The correct response supplied by teachers rose from pre-survey to post-survey. The data also demonstrate that all in-service teachers answer correctly at the end. In fact, some pre-service got it wrong. In addition, the data analysis observation practice primarily focuses on student learning.

\subsection{Pre-and Post-Survey}

Both parties of participants pre-service and pre-service mathematics teachers joined in SUPER-LS program were given pre-and post-survey asked a number of questions consist of open and closed question related to their knowledge and experience of lesson study. For the purpose of this study only question related to observation was used, which is three items: Q1. When to conduct observation in lesson study cycle? Q2. What the focus of observation and Q3. What to do when observe the lesson. The result of the survey can be seen in the following Table 2 .

The data above exhibits that both group of mathematics teachers have shifted their observation knowledge along the SUPER-LS program. This can be seen from the correct answers given by teachers which in pre-survey quite low and it increased in the post-survey. The data also shows that all in-service teachers provide correct answer at the end of the program. On the contrary, a number of pre-service teachers gave the wrong answers. 


\subsection{Observation Reports}

The theme related to observation practice emerges from data analysis is provided in the following Table 3.

Example of the teachers' excerpt related to observation focus appeared from written report and video recordings were provided in the following Table 4.

Table 2. Result of pre and post survey.

\begin{tabular}{lll}
\hline Aspect & Pre-service Group & In Service Group \\
\hline Pre Survey & & \\
$\mathrm{N}$ & 11 & 4 \\
Q1 & Do (27.3\%) & Do (50\%) \\
& See (72.7\%) & See (50\%) \\
Q2 & Instruction Process (90.9\%) & Instruction Process (75\%) \\
& Student's Learning/Thinking (9.1\%) & Student's Learning/Thinking (25\%) \\
Q3 & Observe student (36\%) & Observe student (50\%) \\
& Teach and Assess Student (36\%) & Record and taking note (50\%) \\
& Plan, do, see (27\%) & \\
Post-Survey & & \\
N & 11 & 4 \\
Q1 & Do (18.82\%) & Do (100\%) \\
& See (81.18\%) & See (0\%) \\
Q2 & Instruction Process (27.3\%) & Instruction Process (0\%) \\
& Student's Learning/Thinking (72.7\%) & Student's Learning/Thinking (100\%) \\
Q3 & Observe student and teacher (46\%) & Observe student (50\%) \\
& Recording (54\%) & Record and taking note (50\%) \\
\hline
\end{tabular}

Table 3. Table type styles.

\begin{tabular}{lll}
\hline Themes & Sub themes & Code Frequency \\
\hline Student's Learning & Attempt & 25 \\
& Solving Problem & 20 \\
& Communication and Collaboration & 12 \\
& Challenges & 29 \\
Students' Behavior & Physical Look & 1 \\
& Less attention & 11 \\
Students' Disposition & Curiosity & 6 \\
& Confident & 4 \\
& Responsibility & 5 \\
& Math anxiety & 10 \\
Teacher Performance & Teaching Approach & 5 \\
& Assist student & 9 \\
\hline
\end{tabular}


Table 4. Example of observation.

\begin{tabular}{|c|c|}
\hline Obse & Example of Observation \\
\hline Students' learning & $\begin{array}{l}\text { - "I saw students in this group confuse at the beginning, one } \\
\text { student asked to his friend, other read and reread the problem } \\
\text { given for several times, other asks the teacher for explanation" } \\
\text { - "For group C, I observed } 3 \text { students (Khalif, Andi and Darus) } \\
\text { actively communicate, collaborate and solve difficult problem. } \\
\text { While only one student (Pasha) less participate and passive" } \\
\text { - "I saw only students who sat at the front knew how to proceed } \\
\text { the questions, but when I saw their work on conclusion, all are } \\
\text { wrong. This demonstrated that most students don't know when } \\
\text { addition and subtraction of integer number were used, } \\
\text { indicating the purpose of the lesson not achieve yet" }\end{array}$ \\
\hline $\begin{array}{l}\text { Students' } \\
\text { Behaviours }\end{array}$ & $\begin{array}{l}\text { - "I saw students remain salient, may be they are not used to with } \\
\text { - "Sany people observed their learning" } \\
\text { the teacher move to other group, they stop working" } \\
\text { - "At the beginning none of student in the group initiate to open } \\
\text { worksheet, they just stared on blank paper given, they star work } \\
\text { when teacher approach them" } \\
\text { - "I found one student is sleeping" } \\
\text { - "some students didn't pay attention to the lesson" }\end{array}$ \\
\hline $\begin{array}{l}\text { Students' } \\
\text { Disposition }\end{array}$ & $\begin{array}{l}\text { - "I saw when students don't know what to do, they gave up on } \\
\text { solving problem and say I am not good at math" } \\
\text { - "I saw Cut Rara (student name) passively participate in solving } \\
\text { problem, but after her friend, Riska, directed her, she start } \\
\text { writing something on her paper" } \\
\text { - "they know the formula actually, but they were unconfident, } \\
\text { worried to make a mistake, resulting they could not finished the } \\
\text { task" } \\
\text { - "I found Geralf and Rohit (student name) were curious and } \\
\text { solved problem confidently" }\end{array}$ \\
\hline Teacher & - "teachers need to find way to trigger student to think" \\
\hline Performance & $\begin{array}{l}\text { - "teachers responded to students' question patiently" } \\
\text { - "He assist students quite well, explain everything to students" }\end{array}$ \\
\hline
\end{tabular}

The observation practice emerges from data analysis is focused mostly on student' learning and teacher performance.

\section{Discussion}

The study explores pre-service and in-service mathematics teachers' observation techniques through the implementation of SUPER-LS program as a model of school based TPD. The program enables teachers to practice the lesson study cycle, which entails collaborative lesson planning, lesson implementation and 
observation as well as post-lesson discussion. Their expertise and ability to conduct lesson study and provide daily classroom instruction have been enhanced.

Teachers' observation skills are strengthened by participation in the SUPER-LS program. This is demonstrated by pre and post survey results, which indicate that teachers develop a state knowledge of lesson observation. With this knowledge, teachers are expected to be aware of or perceive the lesson observation as a critical activity in the lesson study process. They are supposed to also acknowledge that the heart of every lesson observation is the need to improve students' learning and quality of teaching. This understanding serves as a solid foundation for conducting efficient lesson observation during the lesson study cycle.

This finding is corresponded with the teachers' observation reports, which identified four main themes of focus observation, three of which were connected to student learning, students' behavior and students' disposition There is only one theme that pertains to teacher performance. The finding of this study corroborated prior findings, namely that it enables to closely observe student over an entire lesson and gain a better understanding of student thinking (Baldry \& Foster, 2019; Thinwiangthong et al., 2020). For example, a teacher stated that that "I saw the students were unsure about what to do, then teachers approach them to explain everything which detrimental to trigger their thinking". While another teacher found that "When Aulia (student name) no idea of what to do to solve the problem, she read the task several times, asked her friends for a clue from teacher, opened her text book or previous note in search of materials related to the tasks, she did her best to solve the problem". These type of observations enable teachers to see instruction from the eyes of the students to determine what student comprehend or struggle with, and to determine which aspect of the lesson, classroom and student themselves to provide a support to barriers. Developing the eyes of the students is, in the view of Japanese educators, the primary purpose of the lesson study (Lewis \& Hurd, 2011).

This study also revealed that teacher scour the classroom for evidence about students learning, behavior, and disposition, including how student thinking changed through the lesson, whether quieter student spoke up to, and whether the student eagerly drew on their prior knowledge to solve a novel problem. As a teacher, they can think more deeply about students during the lessons than is usually possible. This demonstrates that lesson study is feasible as a result of the collaboration between school and university (Boonsena et al., 2019), particularly in enhancing observation skills.

One of intriguing findings from this study is that teachers frequently focus on the surface feature of student learning without delving deeper to explain how it occurs. For example, when teachers said that they observed student attempting solve the problem, they do not specify how they did so, what concept and strategy are students used, what kind of dialogue exist to tract the process. Data analysis have shown that no teacher focus on student dialogue or teacher dialogue during the lesson observation. Indeed, this is a crucial in mathematic class- 
room in order to understand student thinking which worth in developing pedagogical approach to effectively assist students (Yoshida \& Jackson, 2011). This is also in lined with Warwick et al. (2016) who argued that the dialogue of student learning can be closed with an agreement on future pedagogical intentions.

Additionally, the Indonesian teacher overall observation focus is considerably different from the one used by teachers in Japan, where the lesson study originated. This is commonly occurred during the initial trial of lesson study adaption in a community learning, when novel teachers are still in the learning stage. However, as the teacher continues to practice lesson study, they will eventually develop the skill. As Ono et al. (2013) claim that observation is one skill that is central in the lesson study endeavor, therefore, to improve lesson observation skill of Indonesian teachers, we believe it is very important to have experienced lesson study practitioners and knowledgeable others to support teachers and ensure the quality of lesson study.

\section{Conclusion}

Lesson study is rapidly becoming one of the most adopted models of teacher professional development worldwide. It has been used in many mathematics teacher training programs both pre-service and in-service teacher. The study has established school-university partnership mediated lesson study to improve mathematics teacher competency, especially lesson observation skill which is critical in providing data about student learning to be used in the reflection session. This study found that the SUPER-LS program has successfully trained teachers to be a good lesson observer. Most of them know when, how and what to do during the lesson observation. From their practice of lesson study over four open classes, it is found that their observation practices focus more on students learning as it is expected by the lesson study. Only a few of teachers, especially pre-service teacher still observes on teacher performance. The study also reveals that of the practice of observation were not specific or descriptions with a very brief and a vague analysis demonstrating that teachers need to practice the activity frequently and continuously in order to develop the skill. If not, then the goal of lesson study would not be achieved.

\section{Recommendations}

This study suggests some recommendation as follow:

1) Further research is recommended to conduct an extensive study involving other partnerships to further explore the finding of this study.

2) Sustainable and long-term SUPER-LS should be provided to improve pre-service and in-service mathematics teachers' observation skills focusing on students thinking. By understanding student thinking, teachers are able to foster students' learning resulted improvement of quality of teaching.

3) Pre-service mathematics teachers need more exposure to lesson study; hence, university should arrange the course using LS enterprise. 


\section{Acknowledgements}

We are thankful to all participants for being part of this study, the Ministry of Education, Culture, Research and Technology of Republic of Indonesia for funding the SUPER-LS program and Grant "Pengajaran dan Pembelajaran, Universiti Kebangsaan Malaysia” (PDI-2021-039).

\section{Conflicts of Interest}

The authors declare no conflicts of interest regarding the publication of this paper.

\section{References}

Asari, S., Fauziyah, N., \& Uchtiawati, S. (2018). Improving Teacher Pedagogic Competences in Remote Areas through Lesson Study Activity. International Journal of Education and Literacy Studies, 6, 53-62.

Baldry, F., \& Foster, C. (2019). Lesson Study Partnerships in Initial Teacher Education. In P. Wood, D. L. S. Larssen, N. Helgevold, \& W. Cajkler (Eds.), Lesson Study in Initial Teacher Education: Principles and Practices, Emerald Publishing Limited, Bingley, 147-160. https://doi.org/10.1108/978-1-78756-797-920191011

Boonsena, N., Inprasitha, M., Changsri, N., \& Matney, G. (2019). Teachers Learning about Teaching Practice in a Modify Lesson Study. Psychology, 10, 977-988. https://doi.org/10.4236/psych.2019.107064

Bozkurt, E., \& Yetkin-Özdemir, I. E. (2018). Middle School Mathematics Teachers' Reflection Activities in the Context of Lesson Study. International Journal of Instruction, 11, 379-394.

Dudley, P. (2014). Lesson Study: A Handbook (pp. 393-405). LS Developments. https://lessonstudy.co.uk/wp-content/uploads/2012/03/new-handbook-revisedMay14.p df

Farrell, R. (2021). The School-University Nexus and Degrees of Partnership in Initial Teacher Education. Irish Educational Studies. https://doi.org/10.1080/03323315.2021.1899031

Fauziah, A., Ilma, R., Putri, I., Info, A., Learning, C., \& Study, L. (2022). Collaborative Learning through Lesson Study in PMRI Training for Primary School Pre-Service Teacher: The Simulation of Polygon Matter. Infinity Journal, 11, 1-16. https://doi.org/10.22460/infinity.v11i1.p1-16

Fen, T. S., Sam, L. C., \& Meng, C. C. (2017). Changes in Teachers' Reflection. Malaysian Journal of Learning and Instruction, 4, 145-172. https://doi.org/10.32890/mjli.2017.7801

Fernandez, C., Cannon, J., \& Chokshi, S. (2003). A US-Japan Lesson Study Collaboration Reveals Critical Lenses for Examining Practice. Teaching and Teacher Education, 19, 171-185. https://doi.org/10.1016/S0742-051X00102-6

Green, C. A., Tindall-Ford, S. K., \& Eady, M. J. (2020). School-University Partnerships in Australia: A Systematic Literature Review. Asia-Pacific Journal of Teacher Education, 48, 403-435. https://doi.org/10.1080/1359866X.2019.1651822

Hendriana, D., Nugraha, I., Hendayana, S., \& Supriatna, A. (2016). A School-University Partnership Mediated by Lesson Study to Promote Professional Learning in the TCTP Program. Universitas Pendidikan. 
Hendriana, D., \& Supriatna, A. (2016). A School-University Partnership Mediated by Lesson Study to Promote Professional Learning in the TCTP Program. https://www.researchgate.net/publication/342131004

Hummes, V. B., Moll, V. F., \& Breda, A. (2019). Uso combinado del estudio de clases y la idoneidad didáctica para el desarrollo de la reflexión sobre la propia práctica en la formación de profesores de matemáticas. Acta Scientiae, 21, 64-82.

https://doi.org/10.17648/acta.scientiae.v21iss1id4968

Iksan, Z. H. (2017). Reflections on Teaching and Learning of Mathematics through Lesson Study and Video Critique. Advances in Social Sciences Research Journal, 4, 50-61. https://doi.org/10.14738/assrj.41.2499

Khin, K., \& Sin, T. (2021). School-University Partnership : Perceptions and Experiences of School Teachers and Student Teachers on Current Collaboration in Teacher Education in Myanmar. Journal of Adult Leaning, Knowledge and Innovation, 1-14. https://doi.org/10.1556/2059.2021.00050

Larssen, D. L. S., Cajkler, W., Mosvold, R., Bjuland, R., Helgevold, N., Fauskanger, J., Wood, P., Baldry, F., Jakobsen, A., Bugge, H. E., Næsheim-Bjørkvik, G., \& Norton, J. (2018). A Literature Review of Lesson Study in Initial Teacher Education: Perspectives about Learning and Observation. International Journal for Lesson and Learning Studies, 7, 8-22. https://doi.org/10.1108/IJLLS-06-2017-0030

Lewis, C. (2011). Response to Part IV: Seeing the Whole Iceberg-The Critical Role of Tasks, Inquiry Stance, and Teacher Learning in Lesson Study. In L. Hart, A. Alston, \& A. Murata (Eds.), Lesson Study Research and Practice in Mathematics Education (pp. 235-240). Springer. https://doi.org/10.1007/978-90-481-9941-9 18

Lewis, C. (2016). How Does Lesson Study Improve Mathematics Instruction? ZDM, 48, 571-580. https://doi.org/10.1007/s11858-016-0792-x

Lewis, C., \& Hurd, J. (2011). Lesson Study Step by Step: How Teacher Learning Communities Improve instruction. Portsmouth: Heinemann.

Lomibao, L. S. (2016). Enhancing Mathematics Teachers' Quality through Lesson Study. SpringerPlus, 5, Article No. 1590. https://doi.org/10.1186/s40064-016-3215-0

Marsh, B. (2021). Developing a Project within a School-University Partnership: Factors that Influence Effective Partnership Working. Research Papers in Education, 36, 233-256. https://doi.org/10.1080/02671522.2019.1646794

Merriam, S. (2009). Qualitative Research: A Guide to Design and Implementation. San Francisco, CA: Jossey-Bass.

Meyer, D., \& Wilkerson, L. (2011). Lesson Study: The Impact on Teachers' Knowledge for Teaching Mathematics. In L. Hart, A. Alston, \& A. Murata (Eds.), Lesson Study Research and Practice in Mathematics Education (pp. 15-26). Springer. https://doi.org/10.1007/978-90-481-9941-9 2

Murata, A. (2011). Introduction: Conceptual Overview of Lesson Study. In A. Hart, L. C. Alston, \& A. S. Murata (Ed.), Lesson Study Research and Practice in Mathematics Education (pp. 13-24). Springer. https://doi.org/10.1007/978-90-481-9941-9 1

Myers, J. (2012). Lesson Study as a Means for Facilitating Preservice Teacher Reflectivity. International Journal for the Scholarship of Teaching and Learning, 6, Article No. 15.

Myers, J., \& West, O. (2012). The Effects of Lesson Study on Classroom Observations and Perceptions of Lesson Effectiveness. Journal of Effective Teaching, 12, 94-104.

OECD (2016). Overview: Policies and Practices for Successful Schools: Vol. II. https://doi.org/10.1787/9789264267510-5-en

Olson, J. C., White, P., \& Sparrow, L. (2011). Influence of Lesson Study on Teachers' Ma- 
thematics Pedagogy. In A. Hart, L. C. Alston, \& A. S. Murata (Ed.), Lesson Study, Research and Practice in Mathematics Education (pp. 39-57). Springer. https://doi.org/10.1007/978-90-481-9941-9 4

Ono, Y., Chikamori, K., \& Rogan, J. M. (2013). How Reflective are Lesson Study Discussion Sessions? Developing an Instrument to Analyze Collective Reflection. International Journal of Education, 5, 52-67.

Saito, E. (2012). Key Issues of Lesson Study in Japan and the United States: A Literature Review. Professional Development in Education, 38, 777-789. https://doi.org/10.1080/19415257.2012.668857

Saito, E., Imansyah, H., Kubok, I., \& Hendayana, S. (2007). A Study of the Partnership between Schools and Universities to Improve Science and Mathematics Education in Indonesia. International Journal of Educational Development, 27, 194-204. https://doi.org/10.1016/j.ijedudev.2006.07.012

Suratno, T., \& Iskandar, S. (2010). Teacher Reflection in Indonesia : Lessons Learnt from a Lesson Study Program. US-China Education Review, 7, 39-48.

Thinwiangthong, S., Eddy, C. M., \& Inprasitha, M. (2020). Mathematics Teachers' Abilities in Developing Formative Assessment after the Introduction of Lesson Study and Open Approach Innovations. Malaysian Journal of Learning and Instruction, 17, 101-132. https://doi.org/10.32890/mjli2020.17.1.5

Tsui, A. B. M., Edwards, G., Lopez-Real, F., Kwan, T., Law, D. et al. (2009). Learning in School-University Partnership. Routledge. https://doi.org/10.4324/9780203891001

Vermunt, J. D. et al. (2019). The Impact of Lesson Study Professional Development on the Quality of Teacher Learning. Teaching and Teacher Education, 81, 61-73. https://doi.org/10.1016/j.tate.2019.02.009

Warwick, P., Vrikki, M., Vermunt, J. D., Mercer, N., \& van Halem, N. (2016). Connecting Observations of Student and Teacher Learning: An Examination of Dialogic Processes in Lesson Study Discussions in Mathematics. ZDM, 48, 555-569.

https://doi.org/10.1007/s11858-015-0750-Z

Wolthuis, F., van Veen, K., de Vries, S., \& Hubers, M. D. (2020). Between Lethal and Local Adaptation: Lesson Study as an Organizational Routine. International Journal of Educational Research, 100, Article ID: 101534. https://doi.org/10.1016/j.ijer.2020.101534

Wood, P., Cajkler, W., \& Jakobsen, A. (2020). The Role of Observation in ITE Lesson Study. In P. Wood, D. L. S. Larssen, N. Helgevold, \& W. Cajkler (Eds.), Lesson Study in Initial Teacher Education: Principles and Practices, Emerald Publishing Limited, Bingley, 75-88. https://doi.org/10.1108/978-1-78756-797-920191006

Yin, R. (2009). Case Study Research: Design and Methods (4th ed.). Thousand Oaks, CA: Sage.

Yoshida, M. (2012). Mathematics Lesson Study in the United States: Current Status and Ideas for Conducting High Quality and Effective Lesson Study. International Journal for Lesson and Learning Studies, 1, 140-152.

https://doi.org/10.1108/20468251211224181

Yoshida, M., \& Jackson, W. (2011). Idea for Developing Mathematical Pedagogical Content Knowledge through Lesson Study. In A. Hart, L. C. Alston, \& A. S. Murata (Ed.), Lesson Study Research and Practice in Mathematics Education (pp. 279-288). Springer. https://doi.org/10.1007/978-90-481-9941-9 22 